\title{
PENGARUH INFLASI, SUKU BUNGA SBI, KURS US DOLLAR TERHADAP RUPIAH, PAJAK, SOLVABILITAS, DAN PROFITABILITAS TERHADAP STRUKTUR MODAL PADA PERUSAHAAN LQ-45 YANG TERDAFTAR DI BURSA EFEK INDONESIA PERIODE 2010-2015
}

\author{
Budiono $^{1}$, Nur Septiani ${ }^{2}$ \\ Jurusan Manajemen, Fakultas Ekonomi, Universitas Negeri Surabaya ${ }^{1,2}$ \\ budiono.isei@gmail.com ${ }^{1}$ \\ nur.septiani.pluto@gmail.com²
}

\begin{abstract}
The capital structure is the ratio between long-term debt and equity capital used by the company. By using a proper comparison it will obtain an optimal capital structure. Optimal capital structure is capital structure which optimizes the balance between risk and return in order to maximize the stock price. The purpose of this study was to determine the factors that affect the company's capital structure of LQ-45 listed on the Indonesia Stock Exchange 2010-2015 period. The sampling technique used is purposive sampling method that produces as many as 13 companies. The analysis technique used is multiple linear regression. The results showed that all independent variables simultaneously affect the capital structure. T test results showed that the variable of exchange rate of US dollar against the rupiah has significant negative effect on the capital structure, the variable of tax has positive and significant impact on the capital structure, the variable of solvency has positive and significant impact on the capital structure and profitability variable has significant negative effect on the capital structure. While the variable inflation and SBI interest rate has no significant effect on the capital structure.
\end{abstract}

Keywords: Inflation; Interest Rates; Exchange rate of US dollar against the rupiah; tax; solvency, and profitability.

\section{PENDAhULUAN}

Era globalisasi menuntut perusahaan untuk meningkatkan nilai perusahaan melalui segala aktivitas yang dilakukan guna memenangkan persaingan bisnis. Oleh sebab itu, manajer perusahaan perlu memperhatikan keputusan pendanaan yang tepat bagi perusahaan. Keputusan pendanaan merupakan keputusan tentang seberapa penggunaan utang dibanding ekuitas untuk pembiayaan investasi (Sheikh dan Wang, 2011). Selain itu dapat diartikan pula keputusan pendanaan suatu perusahaan adalah keputusan yang harus dilakukan oleh manajer keuangan yang berkaitan dengan analisis biaya dana atau modal yang digunakan perusahaan (Wiagustini, 2010:207).

Menurut Riyanto (2011:5), pemenuhan dana perusahaan dapat berasal dari sumber internal (internal financing) dan sumber eksternal (external financing). Kebutuhan dana perusahaan dari sumber internal yaitu sumber dana yang dihasilkan sendiri dari dalam perusahaan yaitu dapat berupa laba ditahan dan depresiasi. Sedangkan kebutuhan dana eksternal dapat berasal dari para kreditur dan pemilik, peserta atau pengambil bagian di dalam perusahaan.

Pemilihan alternatif sumber dana merupakan keputusan yang sangat strategis dalam suatu perusahaan, karena menyangkut beban finansial jangka panjang. Perusahaan perlu mempertimbangkan apakah dananya dipenuhi dari saham, utang, atau kombinasi dari keduanya. Menurut Brigham dan Houston (2011:153) perusahaan yang sedang berkembang membutuhkan modal yang dapat berasal dari utang maupun ekuitas. Keputusan dalam memilih penggunaan utang dalam pembiayaan investasi akan menentukan struktur modal dalam perusahaan yaitu, proporsi utang dalam struktur sumber pembiayaan jangka panjang. Menurut Putri 


\section{Budiono dan Nur Septiani - Pengaruh Inflasi, Suku Bunga SBI...}

(2012), terlalu banyak utang akan menghambat perkembangan perusahaan dan juga akan membuat pemegang saham berfikir dua kali untuk tetap menanamkan modalnya. Hal ini menjadi salah satu masalah yang timbul dari penentuan struktur modal yang tidak optimal. Masalah struktur modal menarik perhatian bagi sejumlah peneliti, karena sebagian besar perusahaan membutuhkan utang atau penggunaan dana pihak ketiga selain modal swasta (Momami et al., 2010).

Menurut Lawrence (2007) struktur modal adalah perbandingan antara hutang jangka panjang dan modal sendiri yang digunakan oleh perusahaan. Dengan menggunakan perbandingan yang tepat maka akan diperoleh struktur modal yang optimal. Struktur modal yang optimal adalah struktur modal yang mengoptimalkan keseimbangan antara risiko dan pengembalian sehingga dapat memaksimumkan harga saham (Brigham dan Houston, 2011:6). Dengan adanya struktur modal yang optimal maka perusahaan yang mempunyai struktur modal optimal akan menghasilkan tingkat pengembalian yang optimal pula sehingga tidak hanya perusahaan yang memperoleh keuntungan, tetapi para pemegang saham pun ikut memperoleh keuntungan tersebut (Brigham dan Houston, 2006).

Faktor-faktor yang mempengaruhi struktur modal perusahaan menjadi hal penting sebagai dasar pertimbangan dalam menentukan komposisi struktur modal perusahaan. Salah satu faktor yang mempengaruhi struktur modal adalah faktor lingkungan makroekonomi. Bukti empirik terkait dengan pengaruh faktor lingkungan makroekonomi terhadap kebijakan struktur modal ditemukan oleh De Angelo dan Masulis (2006), bahwa inflasi secara teoritis dapat mendorong penggunaan utang karena semakin tinggi inflasi, bunga pinjaman secara relatif menjadi lebih murah. Temuan tersebut didukung oleh Kim dan Wu (2006), serta Franks dan Goyal (2009) yang menyimpulkan bahwa inflasi cenderung meningkatkan penggunaan hutang sehingga meningkatkan struktur modal. Dengan demikian, beberapa penelitian tersebut menyatakan bahwa inflasi berpengaruh positif terhadap struktur modal. Namun hal ini bertentangan dengan hasil penelitian Ratnawati (2007) yang menemukan bahwa variabel inflasi tidak berpengaruh terhadap struktur modal.

Variabel makroekonomi lain yang juga menjadi perhatian adalah nilai suku bunga (interest rate). Pada saat perusahaan merencanakan pemenuhan kebutuhan modal, sangat dipengaruhi oleh tingkat bunga yang sedang berlaku. Hal ini karena tinggi rendahnya tingkat bunga menentukan jenis modal yang akan digunakan. Perusahaan akan mempertimbangkan apakah perusahaan menarik obligasi atau mengeluarkan saham. Pengeluaran saham ditempuh apabila tingkat bunga lebih rendah daripada tingkat earnig power dari tambahan modal tersebut (Riyanto, 2011:297). Berdasarkan penelitian Mufidah (2012) ditemukan bahwa terdapat pengaruh negatif signifikan BI rate terhadap struktur modal perusahaan. Akan tetapi penemuan tesebut bertentangan dengan hasil penelitian Karyawati (2011) yang menyatakan bahwa BI rate tidak berpengaruh signifikan terhadap struktur modal.

Selain inflasi dan tingkat bunga, variabel makroekonomi yang mempengaruhi struktur modal adalah nilai tukar. Menurut Sartono (2008:44) nilai tukar (exchange rates) menunjukkan banyaknya unit mata uang yang dapat dibeli atau ditukar dengan satu satuan mata uang lain. Perusahaan yang dalam kegiatan operasionalnya melibatkan mata uang asing, maka perusahaan tersebut tidak terlepas dari nilai tukar mata uang asing ke mata uang rupiah. Mufidah (2012) dalam penelitiannya menyimpulkan bahwa variabel nilai tukar valuta asing berpengaruh negative dan signifikan terhadap struktur modal. Hal ini mengindikasikan bahwa ketika nilai tukar 
US Dollar terhadap Rupiah naik, maka perusahaan yang memiliki utang dalam mata uang US Dollar akan mengurangi hutangnya, sehingga struktur modal menurun. Akan tetapi penelitian Perdana et al (2015) menemukan hasil yang berbeda dimana perusahaan tidak perlu meperhatikan kurs dalam proses penentuan keputusan pendanaan sehingga tidak berdampak pada struktur modal.

Variabel makroekonomi lainnya yang juga berpengaruh terhadap struktur modal adalah pajak. Hubungan antara pajak dan struktur modal dapat dijelaskan dengan menggunakan Trade off theory, yang menyatakan bahwa perusahaan akan menerima perlindungan dari sisi pajak dengan menggunakan utang yang diperoleh dari pembayaran beban bunga kepada kreditur. Bunga pinjaman merupakan beban yang dapat digunakan untuk mengurangi pajak yang harus dikeluarkan perusahaan. Jadi semakin tinggi tarif pajak perusahaan, maka semakin besar manfaat penggunaan utang sehingga dapat mengoptimalkan struktur modal (Brigham dan Houston, 2011:40). Artinya, semakin tinggi tarif pajak, akan mendorong perusahaan untuk memperbesar utangnya, karena semakin besarnya beban bunga akan dapat mengurangi pajak yang dibayarkan. Oleh karena itu, meningkatnya tarif pajak akan cenderung meningkatkan struktur modal. Dengan demikian ada pengaruh positif dari pajak terhadap struktur modal. Sedangkan hasil penelitian dari Sogorb (2008), Chen dan Strange (2005) menemukan pajak memiliki pengaruh negatif signifikan terhadap struktur modal.

Selain variabel makroekonomi, variabel mikroekonomi juga mempengaruhi struktur modal, salah satunya adalah rasio solvabilitas. Menurut Hanafi dan Halim (2007, 77-88) rasio solvabilitas digunakan untuk mengukur kemampuan perusahaan memenuhi kewajiban-kewajiban jangka panjangnya. Hasil penelitian Helen (2012) menunjukkan bahwa variabel solvabilitas yang diwakili oleh DAR memiliki pengaruh yang positif dan signifikan terhadap struktur modal.

Selain variabel rasio solvabilitas, varibel mikroekonomi lain yang mempengaruhi struktur modal adalah variabel rasio profitabilitas. Profitabilitas menunjukkan kemampuan perusahaan dalam menghasilkan laba. Salah satu ukuran profitabilitas perusahaan adalah Return On Assets (ROA). ROA merupakan tingkat pengembalian atas asset-aset dalam menentukan jumlah pendapatan bersih yang dihasilkan dari aset-aset perusahaan dengan menghubungkan pendapatan bersih ke total aset (Keown, 2010:80). Hasil penelitian Sari dan Haryanto (2013) menyatakan bahwa variabel profitabilitas memiliki pengaruh negatif signifikan terhadap struktur modal. Namun demikian, penelitian Kesuma (2009) menunjukkan bahwa profitabilitas tidak berpengaruh signifikan terhadap struktur modal.

Penelitian ini bertujuan untuk menganalisis pengaruh dari faktor-faktor makroekonomi dan mikroekonomi terhadap struktur modal perusahaan LQ-45 yang terdaftar di Bursa Efek Indonesia selama periode 2010-2015. Sampel yang digunakan dalam penelitian ini adalah perusahaan yang termasuk dalam indeks LQ-45 yang terdaftar di BEI periode 20102015 dengan kriteria tertentu. Penggunaan LQ-45 dikarenakan perusahaan yang tergabung dalam indeks LQ-45 menggambarkan sekelompok saham pilihan yang memenuhi kriteria ranking teratas dalam volume transaksi, nilai transaksi, dan frekuensi transaksi, sehingga banyak pihak yang menyoroti perkembangan perusahaan-perusahaan tersebut terutama pihak investor. Berdasarkan uraian tersebut maka penulis melakukan penelitian tentang "Pengaruh Inflasi, Suku Bunga SBI, Kurs US Dollar terhadap Rupiah, Pajak, Solvabilitas, dan Profitabilitas terhadap struktur modal pada Perusahaan LQ-45 yang terdaftar di Bursa Efek Indonesia Periode 2010-2015”. 


\section{Budiono dan Nur Septiani - Pengaruh Inflasi, Suku Bunga SBI...}

\section{METODE PENELITIAN Jenis Penelitian}

Penelitian ini menggunakan jenis penelitian kausal komparatif (CausalComparative Research), dimana metode ini mengidentifikasi fakta atau peristiwa tersebut sebagai variabel yang dipengaruhi (variabel dependen) dan melakukan penyelidikan terhadap variabel-variabel yang mempengaruhi (variabel independen) (Indriantoro dan Supomo, 2012). Dalam penelitian ini penulis ingin menguji pengaruh inflasi, suku bunga SBI, kurs Rp terhadap US Dollar, dan pajak terhadap struktur modal dengan menggunkan pendekatan kuantitatif.

\section{Sampel Penelitian}

Dalam penelitian ini obyek penelitian yang digunakan adalah semua perusahaan LQ-45 yang terdaftar di Bursa Efek Indonesia periode 2010-2015. Metode pengambilan data yang digunakan adalah purpose sampling, yaitu metode pengambilan data acak yang informasinya diperoleh dengan pertimbangan atau kriteria tertentu (Indrianto \& Supomo, 2012). Data sampling yang digunakan akan memenuhi kriteria sebagai berikut. (1) Perusahaan yang bersangkutan menerbitkan laporan keuangan secara publik dan terdaftar di BEI dari tahun 2010 sampai dengan 2015. (2) Perusahaan bergerak di bidang non finansial. Penelitian mengecualikan perusahaan yang bergerak di bidang finansial, dikarenakan dua alasan, yaitu (a) Perusahaan finansial cenderung memiliki karakteristik keuangan dan penggunaan struktur modal yang berbeda dibandingkan perusahaan non finansial (Kazemi dan Arsani, 2012). (b) Adanya peraturan seperti persyaratan modal minimum pada perusahaan finansial secara langsung dapat mempengaruhi struktur modal (Abor dan Biekpe, 2007; Rajan dan Zingales, 1995). (3) Perusahaan mengggunakan laporan keuangan yang diaudit. (4) Perusahaan menyampaikan laporan keuangan dengan menggunakan mata uang rupiah dari tahun 2010 dampai dengan 2015. (5) Tahun buku berakhir pada tanggal 31 Desember.

\section{Variabel dan Definisi Operasional}

Dalam penelitian ini, yang menjadi variabel dependen adalah struktur modal sedangkan variabel independennya adalah inflasi, suku bunga SBI, kurs Rp terhadap US Dollar, dan pajak.

Struktur modal menggunakan ukuran Debt to Equity Ratio (DER), dihitung berdasarkan laporan keuangan perusahaan setiap tahun.

$$
\text { DER }=\frac{\text { Total Hutang }}{\text { Total Modal }} \times 100 \%
$$

Inflasi dihitung berdasarkan perubahan kenaikan indeks harga konsumen setiap tahun.

$$
I N F=\frac{I H K_{t}-I H K_{t-1}}{I H K_{t-1}}
$$

Suku bunga menggunakan proksi suku bunga SBI (Sertifikat Bank Indonesia) setiap tahun.

$$
S B I=\frac{S B I_{t}-S B I_{t-1}}{S B I_{t-1}}
$$

Nilai tukar dihitung berdasarkan kurs tengah US Dollar terhadap Rupiah setiap tahun.

$$
K U R S_{t}=\frac{K U R S_{t}-K U R S_{t-1}}{K U R S_{t-1}}
$$

Pajak dihitung berdasarkan laporan keuangan perusahaan setiap tahun.

$$
\text { Pajak }=\frac{E B T-E A T}{E B T} \times 100 \%
$$

Solvabilitas menggunakan ukuran Debt to Asset Ratio (DAR), dihitung berdasarkan laporan keuangan perusahaan setiap tahun.

$$
D A R=\frac{\text { Total Utang }}{\text { Total Aset }}
$$

Profitabilitas menggunakan ukuran Return to Asset (ROA), dihitung berdasarkan laporan keuangan perusahaan setiap tahun.

$$
R O A=\frac{\text { Laba Operasi }}{\text { Total Aset }}
$$

\section{Teknik Pengumpulan Data}

Sumber data yang digunakan dalam penelitian ini adalah data sekunder dengan menggunakan teknik pengumpulan data metode dokumentasi. 
BISMA - Bisnis dan Manajemen - Volume 9 No 2 April 2017

Tabel 1. Sumber data sekunder

\begin{tabular}{|c|c|c|}
\hline Variabel & Sumber data & Laman sumber data \\
\hline Inflasi & Badan Pusat Statistik & www.bps.go.id \\
\hline Suku Bunga SBI & Bank Indonesia & www.bi.go.id \\
\hline $\begin{array}{l}\text { Kurs US Dollar terhadap } \\
\text { Rupiah }\end{array}$ & Bank Indonesia & www.bi.go.id \\
\hline Pajak & Bursa Efek Indonesia & www.idx.co.id \\
\hline Debt to Asset Ratio (DAR) & Bursa Efek Indonesia & www.idx.co.id \\
\hline Return to Asset (ROA) & Bursa Efek Indonesia & www.idx.co.id \\
\hline Teknik dan Metode Analis & $\begin{array}{l}D A R \\
R O A\end{array}$ & $\begin{array}{l}=\text { Debt to Asset Ratio } \\
=\text { Return to Asset }\end{array}$ \\
\hline $\begin{array}{l}\text { Dalam penelitian kua } \\
\text { analisis data yang diguna }\end{array}$ & $\begin{array}{l}\text { teknik } \\
\text { rahkan }\end{array}$ & $\begin{array}{l}=\text { error term (kesalahan } \\
\text { oengganggu) }\end{array}$ \\
\hline
\end{tabular}

untuk menjawab rumusan masalah atau menguji hipotesis yang telah dirumuskan menggunakan metode statistik dan dengan bantuan program SPSS 20. Langkahlangkah teknik analisis data pada penelitian ini sebagai berikut, (1) Tabulasi dan perhitungan data variabel (2) Uji asumsi klasik (Uji Normalitas, Uji Multikolinieritas, Uji Autokorelasi, Uji Heteroskedastisitas), (3) Analisis Regresi Linier Berganda.

Analisis linier regresi berganda dengan persamaan sbb:

$$
\begin{aligned}
Y=a+b 1 I N F & +b 2 S B I+b 3 K U R S \\
& +b 4 P a j a k+b 5 D A R \\
& +b 6 R O A+e
\end{aligned}
$$

Dimana:

$\mathrm{Y}=$ Struktur Modal

$a \quad=$ konstanta

$b 1, b 2, b 3, b 4, b 5$ dan $b 6=$ koefisien regresi

INF $\quad=$ Inflasi

SBI = Suku Bunga SBI

KURS = Kurs tengah US Dollar terhadap Rupiah

Pajak = Pajak Perusahaan

Uji Hipotesis (Uji pengaruh secara simultan (Uji $\mathrm{F}$ ), Uji pengaruh secara parsial (Uji t), Koefisien Determinasi).

\section{HASIL DAN PEMBAHASAN}

Data penelitian diolah menggunakan analisis regresi linier berganda dengan aplilkasi SPSS. Sebelum melakukan regresi linier berganda, langkah yang terlebih dahulu dilakukan adalah menguji apakah model regresi memiliki model yang baik atau tidak melalui uji asumsi klasik.

\section{Uji Asumsi Klasik}

Uji asumsi klasik bertujuan untuk menguji agar model regresi tidak bias atau agar model regresi memenuhi asumsi BLUE (Best Linear Unbiased Estimator).

Normalitas

Uji normalitas bertujuan untuk menguji apakah dalam model regresi, variabel pengganggu atau residual memiliki distribusi normal. Dalam penelitian ini uji normalitas dilakukan dengan KolmogorovSmirnov Test. Hasil Uji normalitas tampak pada Tabel 2. 


\section{Budiono dan Nur Septiani - Pengaruh Inflasi, Suku Bunga SBI...}

Tabel 2. Hasil Uji Normalitas

One-Sample Kolmogorov-Smirnov Test

\begin{tabular}{llr}
\hline & & \multicolumn{1}{c}{$\begin{array}{c}\text { Unstandardized } \\
\text { Residual }\end{array}$} \\
\hline $\mathrm{N}$ & Mean & 78 \\
\hline Normal Parameters $^{\mathrm{a}}$ & Std. Deviation & .0000000 \\
& Absolute & .17663508 \\
\cline { 2 - 3 } $\begin{array}{lr}\text { Most Extreme } \\
\text { Differences }\end{array}$ & Positive & .155 \\
\cline { 2 - 3 } & Negative &. .100 \\
\hline Kolmogorov-Smirnov Z & & .051 \\
\hline Asymp. Sig. (2-tailed) & &
\end{tabular}

Uji normalitas dilakukan dengan membandingkan nilai asymp. Sig (2tailed) dengan tingkat signifikansi sebesar 0,05. (Ghozali, 2013). Suatu data dikatakan berdistribusi normal apabila nilai asymp. Sig (2-tailed) > 0,05. Berdasarkan tabel Uji K-S diatas, maka dapat disimpulkan bahwa residual terdistribusi secara normal dimana nilai

asymp. Sig (2-tailed) sebesar 0,051>0,05 yang artinya uji normalitas terpenuhi.

Multikolinieritas, Uji multikolinieritas bertujuan untuk menguji apakah dalam model regresi ditemukan adanya korelasi antar variabel bebas (independen). Model regresi yang baik seharusnya tidak terjadi korelasi di antara variabel independen (Ghozali, 2013).

Tabel 3. Hasil Uji Multikolinieritas

Coefficients $^{\mathrm{a}}$

\begin{tabular}{|c|c|c|c|c|c|c|c|c|}
\hline \multirow[b]{2}{*}{ Model } & & \multicolumn{2}{|c|}{$\begin{array}{l}\text { Unstandardized } \\
\text { Coefficients }\end{array}$} & \multirow{2}{*}{$\begin{array}{c}\begin{array}{c}\text { Standardized } \\
\text { Coefficients }\end{array} \\
\text { Beta }\end{array}$} & \multirow[b]{2}{*}{$\mathrm{T}$} & \multirow[b]{2}{*}{ Sig. } & \multicolumn{2}{|c|}{$\begin{array}{c}\text { Collinearity } \\
\text { Statistics } \\
\end{array}$} \\
\hline & & B & $\begin{array}{l}\text { Std. } \\
\text { Error }\end{array}$ & & & & Tolerance & VIF \\
\hline \multirow[t]{7}{*}{1} & (Constant) & -.679 & .270 & & -2.517 & .014 & & \\
\hline & INF & 1.470 & 1.528 & .060 & .962 & .339 & .579 & 1.727 \\
\hline & SBI & 8.309 & 5.023 & .117 & 1.654 & .102 & .447 & 2.238 \\
\hline & KURS & -.00003295 & .000 & -.155 & -2.090 & .040 & .408 & 2.452 \\
\hline & PAJAK & 1.295 & .385 & .164 & 3.367 & .001 & .944 & 1.059 \\
\hline & $\overline{\mathrm{DAR}}$ & 2.327 & .157 & .821 & 14.812 & .000 & .734 & 1.362 \\
\hline & ROA & -.346 & .167 & -.114 & -2.068 & .042 & .737 & 1.357 \\
\hline
\end{tabular}

a. Dependent Variable: DER

Tabel 3 menunjukkan hasil uji multikolinieritas masing-masing variabel independen. Untuk mendeteksi ada atau tidak adanya multikolinieritas dalam model regresi dapat dilihat dari nilai Variance Inflation Factor. Jika nilai $\mathrm{VIF}<10$ berarti tidak terjadi multikolinieritas diantara masing-masing variabel bebas. (Ghozali, 2013) Berdasarkan tabel tersebut, ke enam variabel independen memiliki nilai VIF masing-masing < 10, yang berarti bahwa tidak terjadi multikolinieritas diantara enam variabel independen tersebut. Dengan demikian, model dalam penelitian 
ini memenuhi syarat uji asumsi klasik yaitu tidak terjadi multikolinieritas.

Autokorelasi, Uji autokorelasi bertujuan menguji apakah dalam model regresi linier ada korelasi antara kesalahan pengganggu pada periode $t$ dengan kesalahan pengganggu pada periode $\mathrm{t}-1$ (sebelumnya). Salah satu cara untuk mendeteksi ada tidaknya autokorelasi adalah dengan uji Durbin-Watson (Ghozali, 2013). Hasil uji autokorelasi tampak pada Tabel 4.

Tabel 4. Hasil Uji Autokorelasi

Model Summary ${ }^{\mathrm{b}}$

\begin{tabular}{lrrrrrr} 
Model & \multicolumn{2}{c}{ R } & R Square & $\begin{array}{c}\text { Adjusted R } \\
\text { Square }\end{array}$ & Std. Error of the Estimate & \multicolumn{2}{c}{$\begin{array}{l}\text { Durbin- } \\
\text { Watson }\end{array}$} \\
\hline 1 & $.917^{\mathrm{a}}$ & .840 & .827 & .18394718 & 1.965 \\
\hline
\end{tabular}

a. Predictors: (Constant), ROA, PAJAK, KURS, DAR, INF, SBI

b. Dependent Variable: DER

Berdasarkan Tabel 4 terlihat bahwa nilai $\mathrm{D}-\mathrm{W}$ sebesar 1,965. Nilai $\mathrm{N}$ atau jumlah sampel pada penelitian adalah sebanyak 78 dan nilai $\mathrm{K}$ yaitu jumlah variabel independen yang digunakan adalah sebesar 6 , maka berdasarkan tabel $\mathrm{D}-\mathrm{W}$ diperoleh nilai $\mathrm{DL}=1,4714$ dan nilai $\mathrm{DU}=1,8009$. Model dikatakan terbebas dari gejala autokorelasi jika memenuhi syarat nilai DU < DW < (4-DU). Jika nilai DU disubstitusikan maka akan diperoleh:

$1,8009<1,965<2,1991$. Hal ini berarti bahwa model tersebut terbebas dari gejala autokorelasi.

Heteroskedastisitas, Uji heteroskidastisitas bertujuan menguji apakah dalam model regresi terjadi ketidaksamaan variance dari residual dari satu pengamatan ke pengamatan lain. Model regresi yang baik adalah yang homoskedastisitas (Ghozali, 2013:139). Salah satu cara untuk mendeteksi ada atau tidak adanya gejala heteroskidastisitas yaitu dengan Uji Glejser.

Hasil uji heteroskedastisitas tampak pada Tabel 5. Jika nilai signifikansi antara variabel independen dengan nilai absolut residual lebih dari 0,05 maka tidak terjadi masalah heteroskedastisitas. Berdasarkan Tabel 4 terlihat bahwa seluruh variabel independen memiliki nilai sig > 0,05 maka dapat disimpulkan model regresi tersebut terbebas dari gejala heteroskedastisitas.

Tabel 5. Hasil Uji Heteroskidastisitas

\begin{tabular}{|c|c|c|c|c|c|c|}
\hline \multicolumn{7}{|c|}{ Coefficients $^{\mathrm{a}}$} \\
\hline \multirow[b]{2}{*}{ Mode } & & \multicolumn{2}{|c|}{$\begin{array}{l}\text { Unstandardized } \\
\text { Coefficients }\end{array}$} & \multirow{2}{*}{$\begin{array}{c}\begin{array}{c}\text { Standardized } \\
\text { Coefficients }\end{array} \\
\text { Beta }\end{array}$} & \multirow[b]{2}{*}{$\mathbf{T}$} & \multirow[b]{2}{*}{ Sig. } \\
\hline & & B & $\begin{array}{l}\text { Std. } \\
\text { Error }\end{array}$ & & & \\
\hline \multirow[t]{7}{*}{1} & (Constant) & -.150 & .162 & & -.926 & .358 \\
\hline & INF & 1.556 & .916 & .229 & 1.699 & .094 \\
\hline & SBI & 1.957 & 3.011 & .100 & .650 & .518 \\
\hline & KURS & -.00001248 & .000 & -.212 & -1.320 & .191 \\
\hline & PAJAK & .842 & .557 & .385 & 1.513 & .167 \\
\hline & DAR & .002 & .094 & .002 & .018 & .986 \\
\hline & $\mathrm{ROA}$ & -.126 & .100 & -.150 & -1.259 & .212 \\
\hline
\end{tabular}

a. Dependent Variable: ABS_RES 


\section{Budiono dan Nur Septiani - Pengaruh Inflasi, Suku Bunga SBI...}

\section{Analisis Regresi Linier Berganda}

Hasil analisis regresi linier berganda sebagaimana tampak dalam Tabel 6 menunjukkan bahwa ada empat variabel bebas yang memiliki pengaruh positif terhadap struktur modal yaitu inflasi, suku bunga SBI, pajak, dan DAR, masing-masing dengan koefisien regresi sebesar 1.470, 8.309, 1.295 dan 2.327. Sementara variabel lainnya yaitu kurs US Dollar terdapat Rupiah dan ROA memiliki pengaruh negatif terhadap struktur modal (DER), masing-masing dengan koefisien regresi sebesar -0.00003295 dan -0.346 .

Tabel 6. Hasil Uji Regresi Berganda

\begin{tabular}{llrrr}
\hline \multirow{5}{*}{ Model } & \multicolumn{4}{c}{ Coefficients $^{\mathrm{a}}$} \\
\hline 1 & \multicolumn{2}{c}{$\begin{array}{c}\text { Unstandardized } \\
\text { Coefficients }\end{array}$} & $\begin{array}{c}\text { Standardized } \\
\text { Coefficients }\end{array}$ \\
\cline { 2 - 5 } & \multicolumn{1}{c}{ B } & Std. Error & Beta \\
\cline { 2 - 5 } & (Constant) & -.679 & .270 & \\
\cline { 2 - 5 } INF & 1.470 & 1.528 & .060 \\
\cline { 2 - 5 } SBI & 8.309 & 5.023 & .117 \\
\cline { 2 - 5 } KURS & -.00003295 & .000 & -.155 \\
\cline { 2 - 5 } PAJAK & 1.295 & .385 & .164 \\
\cline { 2 - 5 } DAR & 2.327 & .157 & .821 \\
\cline { 2 - 5 } ROA & -.346 & .167 & -.114 \\
\hline
\end{tabular}

a. Dependent Variable: DER

\section{Uji Hipotesis}

Uji statistik $F$ bertujuan menguji apakah semua variabel independen yang dimasukkan dalam model mempunyai pengaruh secara bersama-sama terhadap variabel dependen. Apabila tingkat probabilitas atau signifikansinya (Sig.) lebih rendah dari 0,05 maka dapat disimpulkan bahwa semua variabel independen secara bersama-sama berpengaruh terhadap variabel dependen (Ghozali, 2013:98). Hasil uji F tampak pada Tabel 7.

Tabel 7. Hasil Uji F

ANOVA $^{\mathrm{a}}$

\begin{tabular}{llrrrrr}
\multicolumn{1}{l}{ Model } & \multicolumn{1}{c}{$\begin{array}{c}\text { Sum of } \\
\text { Squares }\end{array}$} & Df & $\begin{array}{c}\text { Mean } \\
\text { Square }\end{array}$ & F & Sig. \\
1 & $\begin{array}{l}\text { Regressi } \\
\text { on }\end{array}$ & 12.618 & 6 & 2.103 & 62.153 & $.000^{\mathrm{a}}$ \\
\cline { 2 - 7 } & Residual & 2.402 & 71 & .034 & & \\
\hline & Total & 15.021 & 77 & & & \\
\hline
\end{tabular}

a. Predictors: (Constant), ROA, PAJAK,KURS,

DAR, INF, SBI

b. Dependent Variable: DER

Tabel tersebut memperlihatkan bahwa nilai $\mathrm{F}$ hitung sebesar 62,153 dengan tingkat signifikansi 0,000 lebih kecil dari 0,05 . Hasil analisis tersebut menunjukkan bahwa keenam variable bebas yang digunakan dalam model regresi pada penelitian ini secara simultan berpengaruh terhadap struktur modal.

Uji t bertujuan untuk menguji apakah variabel-variabel independen secara parsial berpengaruh terhadap variabel dependen. Hasil Uji t tampak pada Tabel 8. 
Tabel 8. Hasil Uji t

Coefficients $^{\mathrm{a}}$

\begin{tabular}{|c|c|c|c|c|c|c|}
\hline \multirow[b]{2}{*}{ Mod } & & \multicolumn{2}{|c|}{$\begin{array}{l}\text { Unstandardized } \\
\text { Coefficients }\end{array}$} & $\begin{array}{c}\text { Standardized } \\
\text { Coefficients } \\
\end{array}$ & \multirow[b]{2}{*}{$\mathbf{T}$} & \multirow[b]{2}{*}{ Sig. } \\
\hline & & B & $\begin{array}{l}\text { Std. } \\
\text { Error }\end{array}$ & Beta & & \\
\hline 1 & (Constant) & -.679 & .270 & & -2.517 & .014 \\
\hline & INF & 1.470 & 1.528 & .060 & .962 & .339 \\
\hline & SBI & 8.309 & 5.023 & .117 & 1.654 & .102 \\
\hline & KURS & -.00003295 & .000 & -.155 & -2.090 & .040 \\
\hline & PAJAK & 1.295 & .385 & .164 & 3.367 & .001 \\
\hline & $\overline{\mathrm{DAR}}$ & 2.327 & .157 & .821 & 14.812 & .000 \\
\hline & ROA & -.346 & .167 & -.114 & -2.068 & .042 \\
\hline
\end{tabular}

a. Dependent Variable: DER

Hasil uji $t$ untuk masing-masing variabel independen adalah sebagai berikut:

Variabel inflasi memiliki $\mathrm{t}$ hitung sebesar 0,962 dengan nilai signifikansi sebesar 0,339 (lebih besar daripada 0,05). Hal ini menunjukkan bahwa inflasi tidak berpengaruh signifikan terhadap struktur modal. Hasil ini tidak sesuai dengan hipotesis pertama dalam penelitian ini yang menyatakan bahwa inflasi berpengaruh positif terhadap struktur modal pada perusahaan LQ-45 yang terdatar di Bursa Efek Indonesia periode 2010-2015. Dengan demikian, hipotesis pertama tidak terbukti.

Variabel suku bunga SBI memiliki $t$ hitung sebesar 1,654 dengan nilai signifikansi sebesar 0,102 (lebih besar daripada 0,05). Hal ini menunjukkan bahwa suku bunga SBI tidak berpengaruh signifikan terhadap struktur modal. Hasil ini tidak sesuai dengan hipotesis kedua dalam penelitian ini yang menyatakan bahwa suku bunga SBI berpengaruh negatif terhadap struktur modal pada perusahaan LQ-45 yang terdaftar di Bursa Efek Indonesia periode 2010-2015. Dengan demikian, hipotesis kedua tidak terbukti.

Variabel Kurs US Dollar terhadap Rupiah memiliki t hitung sebesar -2,090 dengan nilai signifikansi sebesar 0,040 (lebih kecil daripada 0,05). Hal ini menunjukkan bahwa Kurs US Dollar terhadap Rupiah berpengaruh negatif dan signifikan terhadap struktur modal. Hasil ini sesuai dengan hipotesis ketiga dalam penelitian ini yang menyatakan bahwa Kurs US Dollar terhadap Rupiah berpengaruh negatif terhadap struktur modal pada perusahaan LQ-45 yang terdaftar di Bursa Efek Indonesia periode 2010-2015. Dengan demikian, hipotesis ketiga terbukti.

Variabel pajak memiliki $t$ hitung sebesar 3,367 dengan nilai signifikansi sebesar 0,001 (lebih kecil daripada 0,05). Hal ini menunjukkan bahwa pajak berpengaruh positif dan signifikan terhadap struktur modal. Hasil ini sesuai dengan hipotesis keempat dalam penelitian ini yang menyatakan bahwa pajak berpengaruh positif terhadap struktur modal pada perusahaan LQ-45 yang terdaftar di Bursa Efek Indonesia periode 2010-2015. Dengan demikian, hipotesis keempat terbukti.

Variabel Solvabilitas (DAR) memiliki t hitung sebesar 14,812 dengan nilai signifikansi sebesar 0,000 (lebih kecil daripada 0,05). Hal ini menunjukkan bahwa Solvabilitas berpengaruh positif dan signifikan terhadap struktur modal. Hasil ini sesuai dengan hipotesis kelima dalam penelitian ini yang menyatakan bahwa Solvabilitas berpengaruh positif terhadap struktur modal pada perusahaan LQ-45 


\section{Budiono dan Nur Septiani - Pengaruh Inflasi, Suku Bunga SBI...}

yang terdaftar di Bursa Efek Indonesia periode 2010-2015. Dengan demikian, hipotesis kelima terbukti.

Variabel profitabilitas (ROA) memiliki $\mathrm{t}$ hitung sebesar -2,068, dengan nilai signifikansi sebesar 0,042 (lebih kecil daripada 0,05). Hal ini menunjukkan bahwa profitabilitas berpengaruh negatif dan signifikan terhadap struktur modal. Hasil ini sesuai dengan hipotesis keenam dalam penelitian ini yang menyatakan bahwa profitabilitas berpengaruh negatif terhadap struktur modal pada perusahaan LQ-45 yang terdaftar di Bursa Efek
Indonesia periode 2010-2015. Dengan demikian, hipotesis keenam terbukti.

Koefisien Determinasi $\left(\mathrm{R}^{2}\right)$ mengukur seberapa besar kemampuan model dalam menerangkan variasi variabel dependen (Ghozali, 2013:97). Nilai koefisien determinasi adalah nol dan satu. Makin besar nilai koefisien determinasi, semakin besar kontribusi dari seluruh variabel independen dalam mempengaruhi variasi atau naik turunnya variabel dependen. Nilai koefisien determinasi dapat dilihat di Tabel 9.

Tabel 9. Koefisien Determinasi $\left(\mathrm{R}^{2}\right)$

Model Summary

\begin{tabular}{|c|c|c|c|c|}
\hline Model & $\mathbf{R}$ & R Square & $\begin{array}{l}\text { Adjusted R } \\
\text { Square }\end{array}$ & $\begin{array}{l}\text { Std. Error of } \\
\text { the Estimate }\end{array}$ \\
\hline 1 & $.917^{\mathrm{a}}$ & .840 & .827 & .18394718 \\
\hline
\end{tabular}

Tabel 9 memperlihatkan bahwa nilai koefisien determinasi (adjusted $\mathrm{R}^{2}$ ) sebesar 0.827 atau $82,7 \%$. Hal ini menunjukkan bahwa kemampuan model dalam menerangkan variasi variabel dependen sebesar $82,7 \%$. Artinya, keenam variabel bebas (Inflasi, Suku bunga SBI, Kurs US Dollar terhadap Rupiah, Pajak, Solvabilitas, dan Profitabilitas) mempengaruhi variabel struktur modal sebesar $82,7 \%$, sedangkan sisanya $17,3 \%$ dipengaruhi oleh variabel lain diluar model dalam penelitian ini.

\section{PEMBAHASAN}

Berdasarkan hasil analisis data yang telah dilakukan, diperoleh pembahasan pengaruh setiap variabel independen terhadap variabel dependen sebagai berikut:

\section{Pengaruh Inflasi terhadap Struktur Modal}

Hasil penelitian ini menunjukkan bahwa inflasi berpengaruh positif tetapi tidak signifikan terhadap struktur modal. Hal ini mengindikasikan bahwa inflasi tidak mempengaruhi keputusan perusahaan LQ-45 dalam kaitannya dengan penentuan struktur modal. Hasil penelitian ini mendukung penelitian Karyawati (2011) yang menyatakan bahwa inflasi tidak berpengaruh terhadap struktur modal. Namun, hasil penelitian ini tidak mendukung penelitian yang dilakukan oleh DeAngelo dan Masulis (2006) yang menyatakan bahwa inflasi memiliki pengaruh positif dan signifikan terhadap struktur modal.

Pengaruh Suku Bunga SBI terhadap Struktur Modal

Hasil penelitian ini menunjukkan bahwa suku bunga SBI berpengaruh positif tetapi tidak signifikan terhadap struktur modal. Temuan ini mengindikasikan bahwa suku bunga SBI yang dikeluarkan oleh Bank Indonesia tidak mempengaruhi perusahaan LQ-45 dalam kebijakan pendanaan perusahaan. Hal ini terjadi karena perusahaan lebih mengutamakan pendanaan dari internal dibanding pendanaan dari eksternal. Preferensi penggunaan dana yang berasal dari sumber internal dilakukan oleh perusahaan dengan pertimbangan bahwa sumber dana internal akan memberikan keamanan (risikonya 
lebih rendah) dibandingkan dengan pendanaan dari ekstenal. Tingkat suku bunga tidak berpengaruh terhadap struktur modal perusahaan karena pendanaan internal tidak berhubungan dengan tingkat suku bunga.

\section{Pengaruh Kurs US Dollar terhadap Rupiah}

Hasil penelitian ini menunjukkan bahwa variabel Kurs US Dollar terhadap Rupiah berpengaruh negatif dan signifikan terhadap struktur modal. Hal ini menunjukkan bahwa naik turunnya nilai tukar US Dollar terhadap Rupiah berpengaruh terhadap penggunaan sumber dana dari hutang dalam struktur modal perusahaan LQ-45. Hal ini mengindikasikan bahwa sebagian besar utang pada perusahaan LQ-45 adalah utang dalam mata uang US\$, sehingga melemahnya rupiah terhadap dollar Amerika (naiknya kurs US Dollar terhadap Rupiah) akan direspon oleh perusahaan dengan mengurangi pinjamannya. Oleh karena itu, naiknya kurs US Dollar terhadap Rupiah diikuti oleh menurunnya struktur modal perusahaan.

Hasil penelitian ini mendukung penelitian Mufidah (2012) yang menyatakan bahwa kurs US Dollar terhadap Rupiah berpengaruh negatiif terhadap struktur modal. Namun, hasil penelitian ini bertentangan dengan penelitian Perdana dkk (2015) yang menyatakan bahwa variabel kurs berpengaruh negatif, tetapi tidak signifikan terhadap struktur modal.

\section{Pengaruh Pajak terhadap Struktur Modal}

Hasil penelitian ini menunjukkan bahwa variabel pajak berpengaruh positif dan signifikan terhadap struktur modal. Perusahaan akan mendapatkan keuntungan dari penghematan pajak atas bunga utang perusahaan. Perusahaan yang memiliki tingkat pajak yang rendah cenderung mengurangi penggunaan utang sehingga struktur modalnya semakin rendah. Sebaliknya, bila pajak perusahaan makin tinggi maka penggunaan utang juga akan semakin tinggi, sehingga struktur modalnya semakin tinggi. Utang akan memberikan manfaat dari pajak, semakin tinggi tarif pajak perusahaan maka semakin besar keuntungan dari penggunaan utang. Salah satu cara mengurangi jumlah pajak yang harus dibayar adalah dengan memanfaatkan biaya bunga dengan menambah jumlah hutang mereka.

Hasil penelitian ini mendukung penelitian yang dilakuan oleh Natalia (2008) yang menyatakan bahwa pajak memiliki pengaruh positif terhadap struktur modal. Akan tetapi, penelitian ini bertentangan dengan penelitian yang dilakukan oleh Hadizah (2009) yang menyatakan bahwa variabel pajak tidak berpengaruh terhadap struktur modal.

\section{Pengaruh Solvabilitas terhadap Struktur Modal}

Hasil penelitian ini menunjukkan bahwa variabel solvabilitas berpengaruh positif dan signifikan terhadap struktur modal. Hasil penelitian ini mendukung penelitian Helen (2012) yang menyatakan bahwa faktor yang paling menentukan besar kecilnya struktur modal adalah solvabilitas yang diukur dengan DAR (Debt to Total Assets Ratio). Semakin tinggi aktiva perusahan semakin tinggi pula kepercayaan investor untuk menanamkan modal kepada perusahaan, karena perusahaan dianggap memiliki kinerja yang baik sehingga akan mendatangkan manfaat bagi para investor. Oleh karena itu, makin meningkatnya total aktiva perusahaan akan cenderung menurunkan DAR. Di sisi lain, meningkatnya total aktiva tersebut juga akan menurunkan penggunaan utang, sehingga struktur modal makin menurun. Oleh karena itu, menurunnya DAR (solvabilitas) berdampak menurunkan struktur modal.

\section{Pengaruh Profitabilitas terhadap Struktur Modal}

Hasil penelitian ini menunjukkan bahwa variabel profitabilitas berpengaruh negatif dan signifikan terhadap struktur 


\section{Budiono dan Nur Septiani - Pengaruh Inflasi, Suku Bunga SBI...}

modal. Perusahaan dengan tingkat pengembalian yang tinggi atas investasi akan mengurangi penggunaan utang. Kemampuan perusahaan untuk menghasilkan laba akan dapat menarik para investor untuk menanamkan dananya guna memperluas usahanya, sebaliknya tingkat profitabilitas yang rendah akan menyebabkan para investor menarik dananya. Sedangkan bagi perusahaan itu sendiri profitabilitas dapat digunakan sebagai evaluasi atas efektivitas pengelolaan badan usaha tersebut. Tingkat pengembalian yang tinggi memungkinkan untuk membiayai sebagian besar kebutuhan pendanaan dengan dana yang dihasilkan secara internal (Ahmed dkk, 2010). Oleh karena itu, naiknya profitabilitas menyebabkan penurunan struktur modal.

Penelitian ini mendukung penelitian yang dilakukan oleh Keown et al. (2010) dan Murhadi (2011) yang menyatakan bahwa variabel profitabilitas berpengaruh negatif dan signifikan terhadap struktur modal. Namun, penelitian ini tidak mendukung penelitian Sulistyowati (2009) yang menyatakan bahwa profitabilitas berpengaruh negatif tetapi tidak signifikan terhadap struktur modal.

\section{KESIMPULAN}

Penelitian ini bertujuan untuk mengetahui pengaruh Inflasi, Suku Bunga SBI, Kurs US Dollar terhadap Rupiah, Pajak, Solvabilitas dan Profitabilitas terhadap Struktur Modal pada perusahaan LQ-45 yang terdaftar di Bursa Efek Indonesia Periode 2010-2015. Berdasarkan hasil analisis data dengan menggunakan regresi linier berganda dan pembahasan yang telah dikemukakan, dapat diambil beberapa kesimpulan sebagai berikut : (1) Inflasi berpengaruh positif tetapi tidak signifikan terhadap struktur modal. Hal ini menunjukkan bahwa tingginya inflasi tidak mempengaruhi struktur modal perusahaan LQ-45. (2) Suku bunga SBI berpengaruh positif tetapi tidak signifikan terhadap struktur modal. Hal ini menunjukkan bahwa tinggi rendahnya suku bunga SBI tidak mempengaruhi struktur modal perusahaan LQ-45. (3) Kurs US Dollar terhadap Rupiah berpengaruh negatif dan signifikan terhadap struktur modal. Hal ini menunjukkan bahwa semakin tinggi kurs US Dollar terhadap Rupiah akan menurunkan struktur modal perusahaan LQ-45. (4) Pajak berpengaruh positif dan signifikan terhadap struktur modal. Hal ini menunjukkan bahwa semkain tinggi pajak yang dibayar oleh perusahaan akan menaikkan struktur modal perusahaan LQ45. (5) Solvabilitas berpengaruh positif dan signifikan terhadap struktur modal. Hal ini menunjukkan bahwa semakin tinggi solvabilitas akan menaikkan struktur modal perusahaan LQ-45. (6) Profitabilitas berpengaruh negatif dan signifikan terhadap struktur modal. Hal ini menunjukkan bahwa semakin tinggi profitabilitas akan menurunkan struktur modal perusahaan LQ-45.

Berdasarkan hasil penelitian yang telah dilakukan maka penulis menyampaikan beberapa saran sebagai berikut (1) Penelitian lebih lanjut mengenai faktorfaktor yang mempengaruhi struktur modal perusahaan LQ-45 perlu dilakukan dengan periode pengamatan yang lebih lama dibandingkan dengan penelitian ini. (2) Perlu diuji ulang atas konsistensi temuan pada penelitian ini dengan mengembangkan metodologi penelitian yang telah dilakukan, pengembangan variabel, perluasan sampel penelitian, pengembangan pengukuran variabel, dan perluasan obyek penelitian. (3) Penentuan struktur modal yang optimal sangat penting bagi manajemen perusahaan. Struktur modal yang optimal adalah struktur modal yang mengoptimalkan keseimbangan antara risiko dan pengembalian sehingga dapat memaksimumkan harga saham. Untuk menentukan struktur modal yang optimal, manajemen perusahaan perlu memperhatikan empat variabel yang memiliki pengaruh signifikan terhadap 
struktur modal yaitu kurs US Dollar terhadap Rupiah, pajak, solvabilitas, dan profitabilitas.

\section{REFERENSI}

Abor, Joshua dan Biekpe, Nicholas. 2007. How Do We Explain The Capital Structure of SMEs in su-Saharan Africa? Evidence From Ghana. Journal economic studies. Vol 36. No.1, 83-97.

Ahmed, Naveed, Zulfqar Ahmed, dan Ishfaq Ahmed. 2010. Determinant of Capital Structure: A Case of Life Insurance Sector of Pakistan. European Journal of Economic, Finance, and Administrative Sciences, 24 (24),pp: 1-6.

Amidu, Mohammed. 2007. Determinants of Capital Structure of Bank in Ghana: an empirical approach. Baltic Journal of Management, Vol. 2 Iss: 1 , pp. $67-79$.

Anwar, Riza'ul. 2009. Analisis pengaruh Tradeoff Theory, Pecking Order Theory, dan Signaling Theory Terhadap Struktur Modal Perusahaan Manufaktur. Skripsi. Jakarta: UIN.

Anwary, Ahmad Amiruddin. 2011. Prediksi Kurs Rupiah Terhadap Dollar Amerika Menggunakan Fuzzy Time Series. Program Studi Teknik Informatika Jurusan Matematika. Fakultas Matematika dan Ilmu Pengetahuan Alam. Universitas Diponegoro. Semarang.

Ariyanti, 2016. Pengaruh Ukuran Perusahaan, Pertumbuhan Perusahaan, dan Profitabilitas terhadap Struktur Modal pada Sektor Pertanian yang Tercatat pada Bursa Efek Indonesia Periode 2011-2014, Skripsi pada Jurusan Manajemen, Fakultas Ekonomi Universitas Negeri Surabaya.

Aziz, Abdul. 2009. Pengaruh Capital Strukture Terhadap Profitabilitas Pada Perusahaan Indistri
Pertambangan Yang Terdaftar di BEI. Skripsi. Jakarta: UIN.

Bank Indonesia. 1998. S.K Direksi BI No.31/67/Kep/DIR, Bank Indonesia, Jakarta.

Bank Indonesia. 2002. Peraturan Bank Indonesia No. 4/10/PBI/2002, Pasal 1 ayat 3 , Bank Indonesia, Jakarta.

Boediono. 2008. Ekonomi Moneter. Yogyakarta: BPFE.

Brealey, Richard A., Stewart C. Myers dan Alan J. Marcus. 2009. Dasar-Dasar Manajemen Keuangan Perusahaan, Jilid Kedua, Edisi Kelima. Jakarta: Erlangga.

Brigham, Eugene F and Joel F.Houston. 2006. Dasar-Dasar Manajemen Keuangan, alih bahasa Ali Akbar Yulianto, Buku satu, Edisi sepuluh. Jakarta: Salemba Empat.

Brigham, E. F., dan Joel, F. H. 2011. Dasar-Dasar Manajemen Keuangan. Jakarta: Salemba Empat.

Burgman. 2007. An Empirical Examination of Multinational Corporate Capital Structure. Journal of International Business Studies, (27) 3: 553-570.

Chen, J., dan Strange, R. 2011. The Determinants of Capital Structure: Evidence from Chinese Listed Companies. Journal Economic Change and Restructring. 12 (2), pp: 11-35.

DeAngelo, H.and R. Masulis. 2006. "Optimal Capital Structure under Corporate and Personal Taxation," Journal of Financial Economics 8, 329.

Frank and Vidham K. Goyal, 2009." Capital Structure Decisions : Which Factors Are Reliably Important," Social Science Research Net work.

Hadizah, S. R. 2009. Faktor-Faktor yang MempengaruhiStruktur Modal PadaPerusahaan Manufaktur yang Terdaftar di Bursa Efek Indonesia.Skripsi.Yogyakarta: Universitas Islam NegeriSunanKalijaga. 
Halim, Abdul. 2013. Analisis Investasi. Jakarta: SalembaEmpat.

Hanafi, M. Mamduh dan Abdul Halim. 2007. Analisis Laporan Keuangan. Yogyakarta : UPP STIM YKPM.

Hapsari, Laksmi Indri. 2010. Analisis Faktor-faktor Yang Mempengaruhi Struktur Modal Pada Perusahaan Manufaktur Yang Terdaftar Di Bursa Efek Indonesia Periode 2006-2008 (Studi Kasus Pada Sektor Automotive and Allied Product). Skripsi. Semarang: Universitas Diponegoro.

Helen. 2012. Pengaruh Rasio Likuiditas, Solvabilitas, Aktivitas, dan Profitabilitas Terhadap Struktur Modal PT Asuransi Sinar Mas (ASM). Skripsi. Depok:UniversitasGunadarma.

Horne, Van, C. James dan Jhon M. Wachowicz. 2007. Prinsip-prinsip Manajemen Keuangan, Edisi 12, Buku Kedua. Jakarta: Salemba Empat.

Husnan, Suad. 2008. Dasar-dasar Manajemen Keuangan. Yogyakarta: UPP-AMP YKPN.

Husnan, Suad dan Pudjiastuti, Enny. 2008.Dasar-Dasar Manajemen Keuangan Edisi 4. Yogyakarta: UPP AMP YKPM.

Indriantoro dan Supomo. 2012.Metodologi Penelitian Bisnis untuk Akuntansi dan Manajemen, Edisi Pertama. Yogyakarta: BPFE.

Kanita, Ghia Ghaida. 2014. "Pengaruh Struktur Aktiva dan Profitabilitas terhadap Struktur Modal Perudahaan Makanan dan Minuman" Volume 13, No. 2, Desember 2014, Hal. 127135.

Karyawati, Endang., Taher Alhabsyi., \& Darminto. 2011. Pengaruh Karakteristik Perusahaan, Faktor Eksternal dan Struktur Modal Terhadap Kinerja Keuangan Perusahaan. Jurnal Profit Volume, 6(2), 69-82.
Kazemi, Mahdi and Zinat Ansari. 2012. "The Impact of Firm Characteristics on Capital Structure of Listed Companies in Tehran Stock Exchange,: American Journal of Scientific Research 42 (1450-223X): 12-23.

Keown, Arthur J. et al. 2008. Manajemen Keuangan : Prinsip dan Penerapan. Jakarta: Salemba Empat.

Keown, Arthur J., Martin, John D., Petty, J. William dan Schott, David F. JR. 2010. Financial Management. Principles and Application, Ninth Edition, New Jersey: Prentice-Hall.

Kesuma, Ali. 2009. Analisis Faktor yang Mempengaruhi Struktur Modal serta Pengharuhnya terhadap Harga Saham Perusahaan Real Estate yang Go Public di Bursa Efek Indonesia. Manajemen dan Kewirausahaan, volume 11(1):38-45.

Kim YC dan Wu, Stulz RM. 2006. Timing, Investment Opportunities, Managerial Discretion, and the Security Issue Decision. Journal Financ2 Econ 42:159-185.

Lawrence J, Gitman. 2007. Principles of Managerial Finance, seventeenth edition. Massachusetts: AddisonWesley Publishing Company.

Mangkoesoebroto, Guritno. 2011. Ekonomi Publik, Edisi-III. Yogyakarta: BPFE.

Manurung , Adler Haymens. 2013. Memahami Seluk Beluk Investasi. Jakarta: PT. Adler Manurung.

Mardiasmo. 2013. Perpajakan, Edisi Revisi. Yogyakarta: Andi.

Momami, G. F., and Dandan, M. 2010. Impact of Firms Characteristic on the Determining the Financial Structure on the Insurance Sectors Firms in Jordan. Journal of Social Science. 6 (2), pp: 282-286.

Mufidah, Ana. 2012. Struktur Modal Perusahaan Properti dan FaktorFaktor yang Mempengaruhinya. Jurnal Bisnis dan Manajemen. 6 (1): 45-54. 
Murhadi, W.R. 2011. Determinan Struktur Modal : Studi di Asia Tenggara. Jurnal Manajemen dan Kewirausahaan, UK Petra, Terakreditasi DIKTI, September 2011.

Natalia,

C.

2008.

PerubahanTarifPPhBadanTerhadapSt ruktur Modal Pada Perusahaan Yang Terdaftar di BEI periode 20062010.JurnalEkonomidanBisnis. 1 (1), pp: 1-5.

Owolabi, Sunday Ajao and Inyang Uduakobong Ema. 2012. Determinants Of Capital Structure In Nigerian Firms: A Theoretical Review.International Journal Of Research In Commerce, Economics \& Management. 2(10), pp:7-11.

Perdana, et al. 2015. Determinan Struktur Modal pada Perusahaan Properti yang Terdaftar di Bursa Efek Indonesia Periode 2009-2013. Artikel Ilmiah Mahasiswa 2015. http://repository.unej.ac.id/bitstream /handle/123456789/64669/NANDA\% 20PERDANA.pdf; sequence $=1$.

Diakses pada tanggal 13 Januari 2017.

Putri, M. E. 2012. "Pengaruh Profitabilitas, Struktur Aktiva dan Ukuran Perusahaan Terhadap Struktur Modal Pada Perusahaan Manufaktur Sektor Industri Makanan dan Minuman yang Terdaftar di Bursa Efek Indonesia (BEI)". Jurnal Manajemen. 1 (1), pp: 1-10.

Rajan, R.G. dan Zingales, I. 1995. What do we know about capital structure? Some evidence from international data, Journal of Finance, Vol. 50: 1421- 1460.

Rao S. N., dan P. J. Lukose. 2013. An Emprical Study on the Determinants of the Capital Structure of Listed Indian Firms. International Journal of Economic. Indian Institute of Technology Bombay, pp: 1-27.

Ratnawati, Tri. 2007. Pengaruh Langsung dan Tidak Langsung Faktor Ekstern,
Kesempatan Investasi dan Pertumbuhan Assets Terhadap Keputusan Pendanaan Perusahaan Yang Terdaftar Pada Bursa Efek Jakarta. Jurnal Akuntansi Dan Keuangan, Vol. 9, No. 2. 65-75.

Riyanto, B. 2011. Dasar-Dasar Pembelanjaan Perusahaan Edisi Keempat Cetakan Ketujuh. Yogyakarta: BPFE.

Riyanto, Bambang. 2007. Dasar-Dasar Pembelanjaan Perusahaan Adisi 4. Jogjakarta : Bagian Penerbitan FE.

Rostami, Jamshid Mohammadzadeh., and Akbarpour, Zohreh. 2012. Study of The Relationship Between Capital Structure and Tax: Evidence from Iran. International Journal of Contemporary Business Studies, 3(11), pp: 35-45.

Rudianto, Dudi, et.al. 2007. Pengaruh Struktur Aktiva dan Ukuran Perusahaan Terhadap Struktur Modal Serta Dampaknya Terhadap Harga Saham Perusahaan Pada Industri Tekstil dan Produk Tekstil Lainnya. Prosiding Seminar Nasional Manjemen Teknologi V, ISBN : 979-99735-2-X, A-44-2.-A44-14.

Sadono, Sukirno. 2011.Makro Ekonomi Modern: Perkembangan Pemikiran dari Klasik hingga Keynesian baru. Jakarta: Raja Grafindo Persada.

Sari, Devi Verena dan Haryanto, A. Mulyo. 2013. Pengaruh Profitabilitas, Pertumbuhan Aset, Ukuran Perusahaan, Struktur Aktiva dan Likuiditas Terhadap Struktur Modal Pada Perusahaan Manufaktur Di Bursa Efek Indonesia Tahun 2008-2010 .Diponegoro Journal Of Management. Vol. 2, No. 3, Tahun 2013, Hal. 1 ISSN : 2337-3792.

Sartono, A. 2008. Manajemen KeuanganTeori dan Aplikasi Edisi 5. BPFE. Yogyakarta.

Sartono, R. Agus dan Ragil Sriharto. 2010. Faktor-faktor Penentu Struktur Modal Perusahaan Manufaktur di 


\section{Budiono dan Nur Septiani - Pengaruh Inflasi, Suku Bunga SBI...}

Indonesia. Sinergi. Vol.2.Hal: 175188.

Sheikh, N. A., dan Zongjun, W. 2011. Determinant of Capital Structure An Empirical Study of Firms in Manufacturing Industry of Pakistan. Journal Managerial Finance. 37 (2), pp: 117-133.

Subagyo, Herry. Faktor Determinasi Struktur Modal (Studi Kasus Perusahaan Manufaktur BEI tahun 2005-2008) Volume 6 Edisi, 2 September 2009, Hal 133-146.

Sugiyono. 2008. Metode Penelitian Bisnis. Bandung: Alfabeta.

Sukirno, Sadono. 2011. Makroekonomi Modern. Jakarta : PT Raja Grafindo Persada.

Sulistyowati, Wiwit Apit. 2009. Penentuan Kebijakan Struktur Modal Pada Perusahaan Manufaktur Di Bursa Efek Indonesia. Jurnal Ilmiah
Mahasiswa Universitas Riau 3 (2) 1-9.

Sundjaja, Ridwan dan Inge Barlian. 2013. Manajemen Keunagan Edisi $\mathrm{Ke}$ empat. Jakarta: Prenhalindo.

Sundjaja, Ridwan S, Inge Barlian, dan Darma Putra Sundjaja. 2007.Manajemen Keuangan I, Edisi Keenam. Bandung: UNPAR Press.

Sogorb, F. 2008. How SME Uniqueness Affects Capital Structure: Evidence From a 1994-1998 Spanish Data Panel. Journal of Economic. pp: 122.

Syamsudin, L. 2009. Manajemen Keuangan. Jakarta: PT. Gramedia.

Wasis. 2009. Pengantar Ekonomi Perusahaan. Salatiga: FKIP UKSW.

Wiagustini, N. L. P. 2010. Dasar-dasar Manajemen Keuangan. Denpasar: Udayana University Press. 